\title{
Influence of Soil Type and Rocky Outcrops on the Species Distribution in a Woody Plant Community at Brazilian Semiarid
}

\author{
José Cícero de Moura ${ }^{1}$, Maria Amanda Nobre Lisboa ${ }^{2}$, Brenda Luana Muniz Gonçalves², Gabriel Venâncio Cruz ${ }^{2}$, \\ Eduardo S. S. Tavares Barreto ${ }^{2}$, Antonio Ivanildo Pinho ${ }^{2}$, Marcos Aurélio Figueiredo dos Santos ${ }^{3}$, \\ Luciana da Silva Cordeiro $^{3}$, Ana Cleide Alcântara Morais Mendonça ${ }^{3}$, Maria Arlene Pessoa da Silva ${ }^{1,3}$, \\ Luiz Marivando Barros ${ }^{1,2}$, Toshik Iarley da Silva ${ }^{4}$, Leonardo Silvestre Gomes Rocha ${ }^{5}$, \\ Marcos Antônio Drumond ${ }^{6}$ \& João Tavares Calixto Júnior ${ }^{1,2}$ \\ ${ }^{1}$ Master's Program in Biological Diversity and Natural Resources, Regional University of Cariri, Crato, Ceará \\ State, Brazil \\ ${ }^{2}$ Laboratory of Studies of the Regional Flora of the Cariri (LEFLORE), Regional University of Cariri, Crato, \\ Ceará State, Brazil \\ ${ }^{3}$ Herbarium Caririense Dárdano de Andrade-Lima (HCDAL), Regional University of Cariri, Crato, Ceará State, \\ Brazil \\ ${ }^{4}$ Doctoral Program in Phytotechnichs, Federal University of Viçosa, Viçosa, Minas Gerais State, Brazil \\ ${ }^{5}$ Department of Animal Biology, Federal Rural University of Rio de Janeiro, Rio de Janeiro, Brazil \\ ${ }^{6}$ Brazilian Agricultural Research Corporation (EMBRAPA Semiárido), Petrolina, Pernambuco State, Brazil \\ Correspondence: João Tavares Calixto Júnior, Laboratory of Studies of the Regional Flora of the Cariri \\ (LEFLORE), Regional University of Cariri, Crato, Ceará State, Brazil. Tel: 55-88-3102-1213. E-mail: \\ joao.calixto@urca.br
}

Received: February 13, 2020

Accepted: March 17, $2020 \quad$ Online Published: April 15, 2020

doi:10.5539/jas.v12n5p155

URL: https://doi.org/10.5539/jas.v12n5p155

\begin{abstract}
Cerrado is a biome that holds many phytophysiognomies, influenced by the edaphic factors, where the type of substrate is strongly related to the established vegetation. This study aims to verify on how soil physicochemical properties, as well as the presence of rocky outcrops, influence the species distribution of woody plants in a Cerrado fragment located in deep soils and tabular relief at Serra do Boqueirão (289 m elev.) Lavras da Mangabeira municipality $\left(6^{\circ} 72^{\prime} 24^{\prime \prime} \mathrm{S} ; 38^{\circ} 97^{\prime} 73^{\prime \prime} \mathrm{W}\right)$, Northeastern Brazil. Every individual with a DNS $\geq 3 \mathrm{~cm}$ in 12 sampling units with an area of $12 \times 30 \mathrm{~m}(0.432 \mathrm{ha})$ was sampled. PAST v. 3.23 software was used in the Main Component analyses. The physical and chemical analyses of the soil were made with samples collected at 0-20 cm and 20-40 cm depths. Differences in diversity, hierarchy and dominance volume of woody plant populations were found between sites with or without the presence of rocky outcrops. The soil has a tendency for water erosion and the aluminum saturation reached values of concentration of $7.9 \mathrm{cmol}_{\mathrm{c}} \mathrm{dm}^{-3}$, with a $\mathrm{pH}$ value between 4.1-4.2 in rocky environments. The obtained results suggest that Q. parviflora and A. occidentale probably have some kind of resistance to the toxicity of aluminum in soil with a pH value below 5.0.
\end{abstract}

Keywords: rocky outcrops, woody plant community, Brazilian semiarid, vegetal ecology, cluster analyses

\section{Introduction}

Brazilian Cerrado is the world's richest savanna in terms of biodiversity (Silveira, 2010), with 11,000 species of native plants are already cataloged (Klink \& Machado, 2005). It ranges through an estimated area of 2,036,448 $\mathrm{Km}^{2}$, exclusively in Brazil (IBGE, 2018), covering 23\% of the national territory (Ribeiro \& Walter, 2008; Mota et al., 2014). Cerrado sensu stricto is found in high elevation reliefs, mainly in deep and well-drained soils, having an herbaceous layer dominated by grasses and a woody layer with diverse heights, varying mainly from three to five meters (Felfili \& Fagg, 2007).

Ribeiro and Walter (2008) determined 11 phytophysiognomic types for the Cerrado biome, distributed between forest, savanic and prairie formations, with Cerrado sensu stricto having the largest territorial extension, occupying ca. 70\% of the biome (Felfili et al., 2013; Mota et al., 2014). This pattern promotes a greater diversity 
of subtypes, as landscapes with typic dense and thin vegetation over deep soils and rocky landscapes with shallow soils and rocky outcrops conditioning the presence of bushes and arboreal vegetation (Ribeiro \& Walter, 2008; Mota et al., 2014).

Some of the main influencing factors on the vegetation types of Cerrado are largely related to the edaphic conditions, especially the following: water depth, drainage, actual soil profile depth and texture, as well as the percentage of exposed rocks (Haridasan, 2000; Abreu et al., 2012). These factors influence Cerrado phytophysiognomies as much as anthropic action does (Pivello \& Coutinho, 1996; Neri et al., 2007).

The Cerrado soil chemical composition is mostly dystrophic, with low $\mathrm{pH}$, low available calcium and magnesium concentrations and high exchangeable aluminum concentration (Lopes \& Cox, 1977; Neri et al., 2007). Depending on concentration level, some metals, such as aluminum, cause soil toxicity, influencing the growth of some native plant species and acting as one of the limiting factors for the growth of some plant species of the Cerrado dominion (Balbino-Miguel et al., 2010).

Abreu et al. (2012) suggest that comparative studies on woody vegetation and rocky outcrops in typical Cerrado sites can aid on the evaluation of the effects of edaphic conditions in their floristic and structural compositions.

For the execution of biodiversity conservation projects and sustainable managing plans, the knowledge of the vegetation, its limitations and resilience on the area of interest is necessary (Ferraz et al., 2013).

Castro (1994) warned about the lack of knowledge on the floristic heritage of Cerrado, which can negatively influence the supply of genetic variability for the future technological generations, and the high phytodiversity and compartimentalized architecture of the Cerrado biome difficults extrapolation of the results achieved by quantitative floristic surveys.

The few Cerrado regions on Southern Ceará state are restrict to enclaves of small sedimentary reliefs, first identified by Figueiredo and Fernandes (1987), located at Lavras de Mangabeira, Aurora, Granjeiro, Várzea Alegre, Farias Brito, Cedro and Jucás municipalities and over the Chapada do Araripe (Figueiredo, 1997; Moro et al., 2011; Nepomuceno et al., 2016). Little is known on the diversity of fauna/flora, structure and conservation status of those Cerrado fragments.

In face of the demand for scientific knowledge on this biome and looking forward to support recover and preservation actions on it, this study aims to analyze on how the physicochemical composition of the soil, as well as the presence of rocky outcrops influence the patterns of floristic distribution and phytophysiognomic structure of woody species in that fragment of Cerrado strictu senso located in the crystalline Caatinga, Brazilian Semiarid.

\section{Methods}

\subsection{Area of Study}

Serra do Boqueirão is located at the municipality of Lavras da Mangabeira $\left(6^{\circ} 72^{\prime} 24^{\prime \prime} \mathrm{S} ; 38^{\circ} 97^{\prime} 73^{\prime \prime}\right.$ W) (Figure 1), at an elevation from 282 to $401 \mathrm{~m}$ above sea level. This municipality belongs to the semiarid portion of Northeastern Brazil, officialy regionalized as Lavras da Mangabeira microregion and Southern-Central Ceará mesoregion (IBGE, 2010). The local site on study lies near the Lavras da Mangabeira sedimentary basin, a set of three small basins covering circa $60.27 \mathrm{~km}^{2}$ in a private property, surprisingly well-preserved, without any agropecuary activity. The climate is defined as Warm Tropical Semiarid (Aw), according to the Köppen classification, with two well-defined seasons (dry winters and humid summers), despite the transitory nature of the semiarid climate on Northeastern Brazil (BSh). The average annual pluviosity is $908.9 \mathrm{~mm}$ (FUNCEME, 2019), the rain season being from January to April. The average annual temperature is $26.8^{\circ} \mathrm{C}$ (INPE, 2019). 


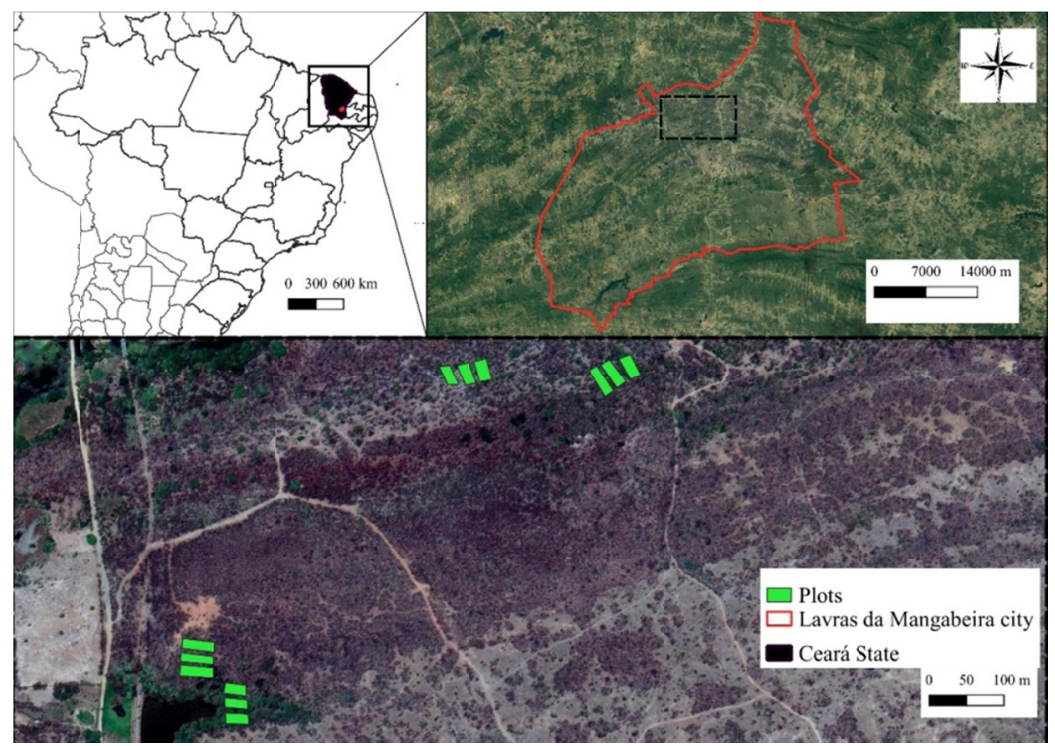

Figure 1. Geographical location of Serra do Boqueirão, Lavras da Mangabeira, Southern Ceará, Brazil

The relief consists on desiccated structural crystal surfaces, with elongated dales and interfluvia. The interfluvia are in an advanced desiccation process, with narrow horizontal surfaces, having parallel grooves in their strands, usually following the fractures (Figueiredo \& Fernandes, 1987). The region is part of the Salgado river basin, with the open bushy Caatinga and dense bushy Caatinga as dominant vegetation. Soil types vary between Argisoil, Luvisoil e Neosoil (IPECE, 2019). This region has rocky outcrops even in higher elevations.

\subsection{Data Collection and Treatment}

The sampling of arboreous-arbustive vegetation was conducted by a forest inventory based on the parcel method (Mueller-Dombois \& Ellemberg, 1974). Twelve sampling units $\left(360 \mathrm{~m}^{2}-12 \times 30 \mathrm{~m}\right)$ were lauched within the distance of $100 \mathrm{~m}$, six of them in a site with no rocky outcrops (Environment $\mathrm{I}$ ) and the remaining six in a site with rocky outcrops (Environment II), in a higher elevation area, totalizing an area of 0.432 ha. Each individual with a DNS (30 cm height from soil diameter) $\geq 3 \mathrm{~cm}$ was registered. DNS was measured with a dendrometric t-bevel, and total height (HT) was estimated using a telescopic graduate rod (Ferraz et al., 2013). In case of existence of resprout, the one of greater diameter and within the inclusion criterions was measured, and the remaining were included, as suggested by Rodal (1992). For the inclusion of the remaining resprouts the following formula was used below proposed by Mota et al. (2014):

$$
\mathrm{DNSf}=\sqrt{\mathrm{DNS}_{1}{ }^{2}+\mathrm{DNS}_{2}{ }^{2}+\ldots+\mathrm{DNS}_{\mathrm{n}}{ }^{2}}
$$

To obtain the phytosociological parameter of Absolute Dominance (DA), the software Fitopac 2.1.2 (Shepherd, 2010) was used.

The botanical determination of the specimens was based in floral and vegetative morphological characters and with the use of botanical collections, by comparison of collected exsiccates with determined material at Herbário Caririense Dárdano de Andrade-Lima, Universidade Regional do Cariri (HCDAL-URCA) and Herbário Prisco Bezerra, Universidade Federal do Ceará (EAC-UFC), in addition to expert and literature consulting. Family-level classification follows the system of Angiosperm Phylogeny Group IV-APG IV 2016 and the spelling of taxa was checked at the data banks of Missouri Botanical Garden (2008) and Flora do Brasil 2020 (Brasil, 2019).

The rock cover evaluation followed the criterions of Mota et al. (2014), adapted in all parcels to the Braun-Blanquet value scale (Mueller-Dombois \& Ellenberg, 1974). The grades were given to the outcrops by the same observer and varied from zero to four, depending on the frequency of the outcrop in each parcel, being zero for absence; one: $1-25 \%$ of occurrence in the parcel; two: $26-50 \%$ of occurrence in the parcel; three: $51-75 \%$ and four: $76-100 \%$. The value of the grade given to each parcel was used as a categoric variable in the multivariate analysis matrix (Mota et al., 2014). The parcels with a grade $\geq 3$ were classified as a rocky outcrop landscape (Environment II). 
In the soil analysis, samples were collected from two different areas (Environments I and II), at the depths of 0-20 and 0-40 cm, (Drumond \& Calixto-Junior, 2018) and taken to the Water and Plant Lab, EMBRAPA Semiárido (Petrolina, Pernambuco State) to obtain the physical and chemical values and attributes of the soil.

To evaluate the relationship between soil chemical attributes and floristic diversity at Environments I and II, a Principal Component Analysis (PCA), using the software PAST v.3.23 (Hammer et al., 2001) was made. This is an indirect sorting technique, originally descript by Pearson (1901) and introduced in vegetation studies by Órloci (1966). The components generated in PCA are sets of independent, uncorrelated variables, with normal distribution. In the generated component matrix, each sampling unit (parcel) has a value for each species and for each environmental variable. Each individual (species) has a value for each component, and receive together the name of component values, which vary in importance, being of interest to show the most significative and/or main (Filfili et al., 2013).

\section{Results}

\subsection{Diversity on Environments I and II}

In the presence/absence of rocky outcrop analysis, parcels were sorted in two environments: Environment I (without rocky outcrops) with sampling units 1, 2, 6, 7, 8 and 9; and environment II (with rocky outcrops) with sampling units 3, 4, 5, 10, 11 and 12 .

The phytosociological survey encountered 906 individuals distributed in 46 species, 43 genera and 22 botanical families. In environment I, 45 species were registered, and in environment II, there were 31 species.

The most representative families in environment I (Table 1) were: Fabaceae (10 spp.), Bignoneaceae (4 spp.), Malvaceae (4 spp.), Rubiaceae and Salicaceae, both with three species. In environment II, family Fabaceae had 5 species; Bignoneaceae (3), Rubiaceae, Salicaceae, Vochysiaceae and Anacardiaceae had 2 species, pointing to a significative reduction of species richness in comparison with environment I.

In relation to the number of individuals, $559(61.6 \%)$ of the 906 measured specimens were sampled at environment I and 347 (38.4\%) at environment II. The species with highest absolute dominance values were: Anacardium occidentale (3.01); Hymenaea stignocarpa (1.29); Qualea parviflora (1.04) Callisthene fasciculata (0.66) and Annona leptopetala (0.66).

\subsection{Multivariate Analysis (PCA)}

The PCA analysis for the distribution of species between the two environments related $H$. stigonocarpa (Fabaceae), A. leptopetala (Annonaceae); C. fasciculata (Vochysiaceae), Guettarda virbunoides and Psdium mysinites as the ones obtaining the most significative values for Environment I axis (Figure 2). The analysis also demonstrated that Astronium fraxilifoium (Anacardiaceae), Dalbergia cearenses (Fabaceae) and Handroanthus impetiginosus (Bignoniaceae) are the species with more similar values between the two main component axes, suggesting that these species are more homogeneously distributed between the two environments. Q. parviflora (Vochysiaceae) and A. occidentale (Anacardiaceae) had the most representative values for the Environment II axis, pointing that these species dominate environments where there are rocky outcrops.

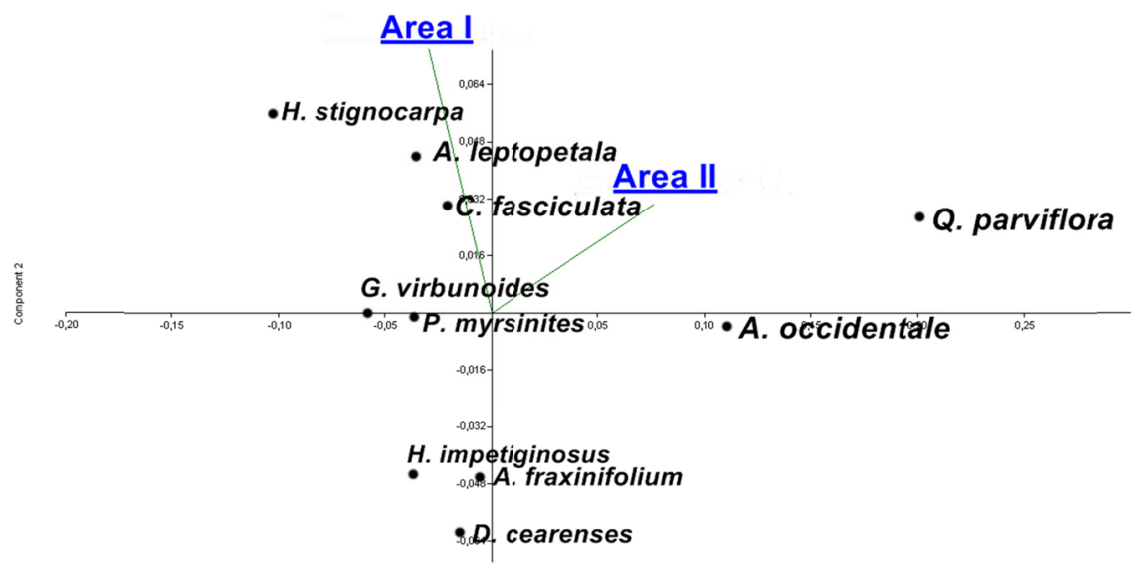

Figure 2. Ordering diagram of Principal component analysis (PCA) of 10 most representative species on two substrate tpes of a Cerrado fragment at Serra do Boqueirão, Lavras da Mangabeira, Ceará, Brazil 
Table 1. Floristic composition of a Cerrado Sensu stricto, Serra do Boqueirão, Lavras da Mangabeira, Ceará, Brazil

\begin{tabular}{|c|c|c|c|c|c|}
\hline Family & Species & Common name & Area I & Area II & $\mathrm{AD}$ \\
\hline \multirow{2}{*}{ Anacardiaceae } & Anacardium occidentale var. microcarpum & Cajuí & 10 & 61 & 3.01 \\
\hline & Astronium fraxinifolium Schott & Gonçalo-Alves & 12 & 18 & 0.42 \\
\hline Annonaceae & Annona leptopetala (R.E.Fr.) H.Rainer & Bananinha & 65 & 20 & 0.42 \\
\hline \multirow{2}{*}{ Apocynaceae } & Aspidosperma cuspa (Kunth) S.F.Blake & Pereiro-branco & 20 & 9 & 0.10 \\
\hline & Aspidosperma pyrifolium var. molle (Mart.) Müll.Arg. & Pereiro-preto & 5 & 7 & 0.06 \\
\hline \multirow{4}{*}{ Bignoniaceae } & Cuspidaria argentea (Wawra) Sandwith & Cipó-rosa & 5 & 14 & 0.08 \\
\hline & Handroanthus impetiginosus (Mart. ex DC.) Mattos & Ipê-roxo & 19 & 8 & 0.28 \\
\hline & Tabebuia aurea (Silva Manso) Benth \& Hook.f. ex S. Moore & Craibeira & 6 & 9 & 0.21 \\
\hline & Jacaranda caroba (Vell.) DC. & Caroba-bocade-sapo & 6 & Aus. & 0.06 \\
\hline Bixaceae & Cochlospermum vitifolium (Willd.) Spreng. & Pacoté & 4 & 1 & 0.09 \\
\hline Burseraceae & Commiphora leptophloeos (Mart.) J.B.Gillett & Umburana-de-cambão & 2 & 1 & 0.04 \\
\hline Cactaceae & Cereus jamacaru DC. & Mandacaru & 1 & 4 & 0.10 \\
\hline \multirow{2}{*}{ Combretaceae } & Combretum glaucocarpum Mart. & Sipaúba & 4 & 1 & 0.12 \\
\hline & Combretum leprosum Mart. & Mofumbo & 4 & Aus. & 0.02 \\
\hline Dilleniaceae & Curatella americana $\mathrm{L}$. & Lixeira & 6 & 5 & 0.38 \\
\hline Euphorbiaceae & Croton jacobinensis Baill. & Marmeleiro & 5 & Aus. & 0.02 \\
\hline \multirow{11}{*}{ Fabaceae } & Dahlstedria araripensis (Benth.) & Angelim & 6 & 9 & 0.66 \\
\hline & Amburana cearensis (Allemão) A.C.Sm. & Umburana-de-cheiro & 5 & 1 & 0.05 \\
\hline & Dalbergia cearenses Ducke & Violete & 6 & 13 & 0.45 \\
\hline & Plathymenia reticulata Benth. & Pau-amarelo & 16 & 10 & 0.39 \\
\hline & Luetzelburgia auriculata (Allemão) Ducke & Pau-mocó & Aus. & 1 & 0.07 \\
\hline & Hymenaea stigonocarpa Mart. ex Hayne & Jatobá-de-veado & 85 & Aus. & 1.29 \\
\hline & Bauhinia sp. & Pata-de-vaca & 5 & Aus. & 0.02 \\
\hline & Libidibia ferrea (Mart. ex Tul.) L.P.Queiroz & Pau-ferro & 4 & Aus. & 0.03 \\
\hline & Machaerium acutifolium Vogel & Coração-de-negro & 7 & Aus. & 0.17 \\
\hline & Mimosa tenuiflora (Willd.) Poir. & Jurema-preta & 2 & Aus. & 0.00 \\
\hline & Vatairea macrocarpa (Benth.) Ducke & Amargoso & 2 & Aus. & 0.01 \\
\hline Lythraceae & Lafoensia vandelliana Cham. \& Schldt. Subsp. vandelliana & Romã-brava & 20 & 1 & 0.08 \\
\hline Malpighiaceae & Byrsonima gardneriana A. Juss. & Murici & 11 & 1 & 0.06 \\
\hline \multirow{4}{*}{ Malvaceae } & Helicteres macropetala A. St.-Hil. & Saca-rolha & 2 & Aus. & 0.01 \\
\hline & Luehea candicans Mart. \& Zucc. & Açoita-cavalo1 & 8 & Aus. & 0.04 \\
\hline & Luehea paniculata Mart. \& Zucc. & Açoita-cavalo2 & 3 & 1 & 0.06 \\
\hline & Pseudobombax marginatum (A.St.-Hil., Juss. \& Cambess.) A.Robyns & Embiratanha & 2 & Aus. & 0.01 \\
\hline Moraceae & Brosimun gaudichaudii Trécul & Inharé & 18 & 2 & 0.39 \\
\hline Myrtaceae & Psidium myrsinites DC. & Araçá-bravo & 42 & 14 & 0.24 \\
\hline \multirow[t]{2}{*}{ Olacaceae } & Ximenia americana $\mathrm{L}$ & Ameixa & 5 & 2 & 0.02 \\
\hline & Coutarea hexandra (Jacq.) K.Schum. & Quína-Quina & 2 & Aus. & 0.00 \\
\hline \multirow[t]{2}{*}{ Rubiaceae } & Guettarda viburnoides Cham. \& Schltdl. & Veludo-branco & 47 & 7 & 0.60 \\
\hline & Tocoyena formosa (Cham. \& Schltdl.) K.Schum. & Jenipapo & 3 & 1 & 0.01 \\
\hline \multirow[t]{2}{*}{ Rutaceae } & Zanthoxylum sp. & Laranjinha & 2 & 4 & \\
\hline & Laetia sp. & Pau-piranha & 4 & 1 & \\
\hline \multirow[t]{2}{*}{ Salicaceae } & Prockia crucis P. Browne ex L. & Farinha-seca & 1 & Aus. & \\
\hline & Xylosma ciliatifolia (Clos) Eichler & Espinho-de-judeu & 3 & 2 & \\
\hline Simaroubaceae & Simarouba amara Aubl. & Pau-Paraíba & 8 & Aus. & 0.02 \\
\hline \multirow{2}{*}{ Vochysiaceae } & Qualea parviflora Mart. & Pau-terra & 7 & 94 & 1.04 \\
\hline & Callisthene fasciculata Mart. & Carvoeiro & 55 & 23 & 0.66 \\
\hline
\end{tabular}

Note. Area I = Environment without rocky outcrops; Area II = Environment with rocky outcrops; AD = Absolute dominance e Aus. $=$ Absent species for this environment.

\subsection{Physical/Chemical Aspects of the Soil}

The kind of substrate in which the plant community grows, according to the classification of IPECE (2019) for the $1^{\text {st }}$ cathegoric level are variations of Neosoil and Luvisoils. Granulometric tests, according to textural classification triangle (Lemos \& Santos, 1984) (Figure 3) demonstrate a sandy soil with variations between the classes "franco-arenoso" and "areia franca" for environment I and just "areia franca" for environment II. 


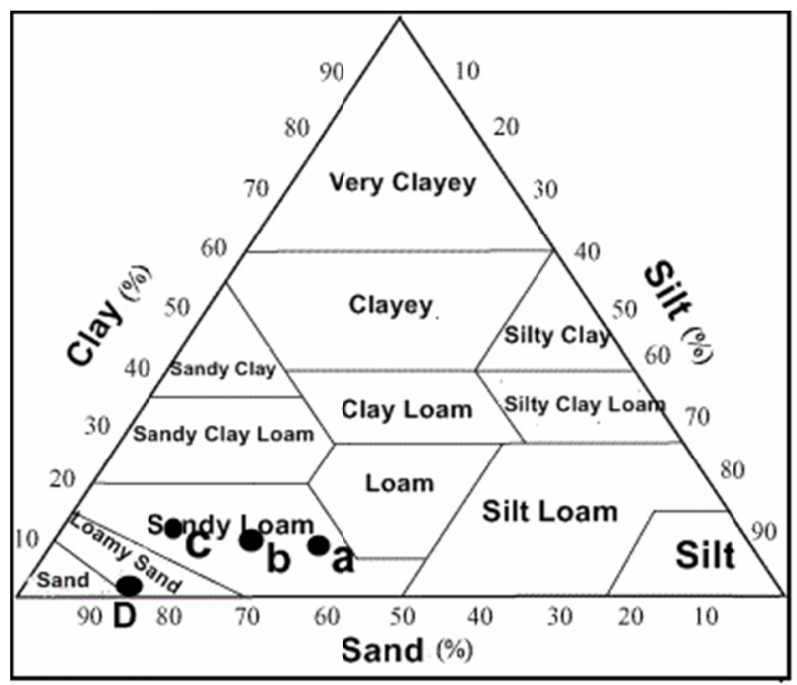

Figure 3: Soil textural classification triangle of a Cerrado Sensu stricto fragment at Serra do Boqueirão, Lavras da Mangabeira, Ceará, Brazil. Adapted from Lemos and Santos (1984)

Note. $\mathrm{a}=$ soil sample taken at depths of $0-20 \mathrm{~cm}$ and $\mathrm{b}=$ samples taken at depths of $0-40 \mathrm{~cm}$ in a rocky outcrop environment; $\mathrm{c}=$ samples taken at depths of $0-20 \mathrm{~cm}$ and $\mathrm{D}=$ samples taken at depths of 0-40 in environments without rocky outcrops.

The results obtained for porosity (Table 2 ) are over $50 \%$ in both substrates, in wich this value $(51.47 \%$ ) was reached at the $0-20 \mathrm{~cm}$ level for environment I and for environment II porosity is even higher, varying from 53.82 to $54.77 \%$ also the $0-20 \mathrm{~cm}$ level.

Table 2. Analytical result-soil physics of a Cerrado Sensu stricto fragment located at Serra do Boqueirão, Lavras da Mangabeira, Southern Ceará, Brazil. Carried out by Soil, water and plant analysis laboratory, Taniguchi (2018)

\begin{tabular}{lll}
\hline Substrate & Soil density $\left(\mathrm{Kg} / \mathrm{dm}^{3}\right)$ & Porosity $(\%)$ \\
\hline Area I $(0-20 \mathrm{~cm})$ & 1.316 & 51.47 \\
Area I $(20-40 \mathrm{~cm})$ & 1.392 & 47.45 \\
Area II $(0-20 \mathrm{~cm})$ & 1.166 & 54.77 \\
Area II $(20-40 \mathrm{~cm})$ & 1.223 & 53.82 \\
\hline
\end{tabular}

Regarding chemical attributes, PCA (Figure 4) showed a high concentration of Aluminum (Al) $\left(1.00 \mathrm{cmol}_{\mathrm{c}}\right.$ $\left.\mathrm{dm}^{-3}-0-20 \mathrm{~cm} / 1.15 \mathrm{cmol}_{\mathrm{c}} \mathrm{dm}^{-3}-20-40 \mathrm{~cm}\right)$ and higher acidity $(\mathrm{pH}: 4.2-0-20 \mathrm{~cm} / 4.1-20-40 \mathrm{~cm})$ for environment II (Table 3). The values for the potassium concentration (K); Sodium (Na), Calcium (Ca) and Magnesium $(\mathrm{Mg}$ ) were also recorded in larger amounts in the rocky substrate, however, in low concentration for both study sites. Aluminum saturation reached high levels in the deepest horizons of soil in environment II (7.9 $\left.\mathrm{cmol}_{\mathrm{c}} \mathrm{dm}^{-3}-20-40 \mathrm{~cm}\right)$. 


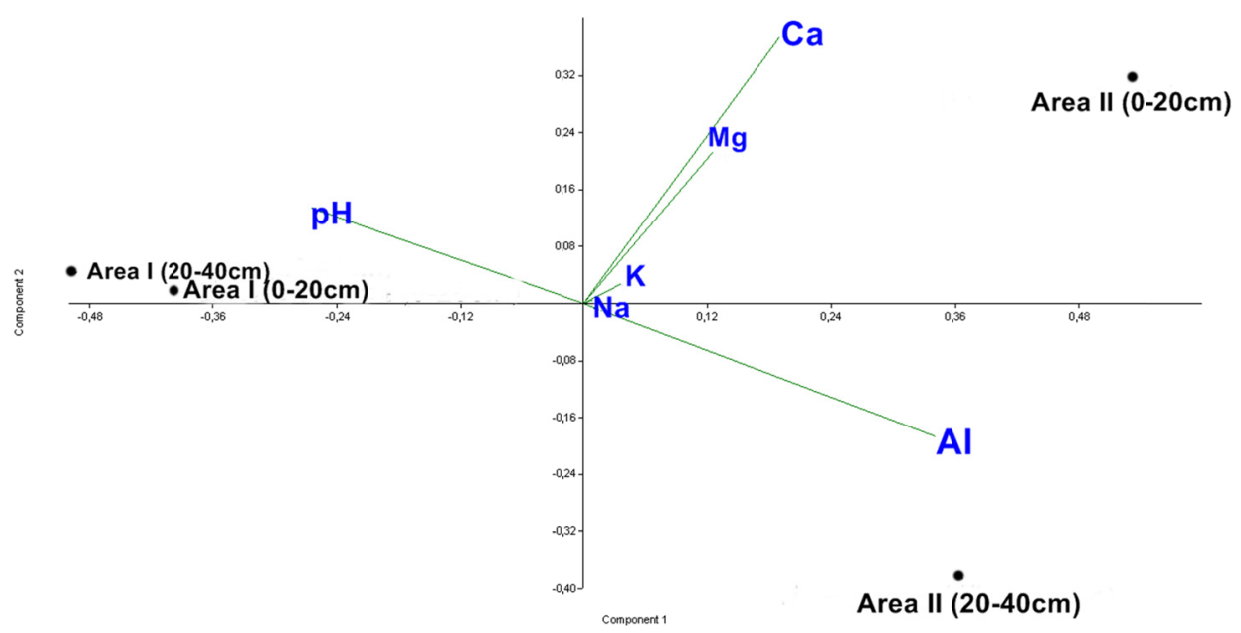

Figure 4. Multivariate Principal Component Analysis (PCA) of soil chemical attributes in a Cerrado Sensu stricto fragment at Serra do Boqueirão, Lavras da Mangabeira, Ceará, Brazil

Note. Environment I = substrates without rock outcrops; Environment II = substrates with rocky outcrops; $\mathrm{Al}=$ aluminum; $\mathrm{K}=$ Potassium; $\mathrm{Na}=$ Sodium $; \mathrm{Ca}=$ Calcium and $\mathrm{Mg}=$ Magnesium.

Table 3. Chemical soil analysis of a Cerrado senso stricto fragment at Serra do Boqueirão, Lavras da Mangabeira, Southern Ceará, Brazil. Soil, water and plant analysis laboratory, Taniguchi (2018)

\begin{tabular}{|c|c|c|c|c|c|c|c|}
\hline Substrate & $\mathrm{pH}$ & $\mathrm{K}$ & $\mathrm{Na}$ & $\mathrm{Ca}$ & $\mathrm{Mg}$ & $\mathrm{Al}$ & $\mathrm{Al}+\mathrm{H}$ \\
\hline & & \multicolumn{6}{|c|}{ 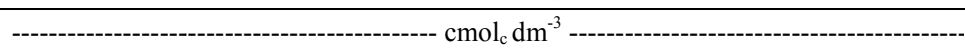 } \\
\hline Area I $(0-20 \mathrm{~cm})$ & 4.6 & 0.16 & 0.10 & 0.5 & 0.45 & 0.45 & 2.4 \\
\hline Area I (20-40 cm) & 4.7 & 0.20 & 0.10 & 0.5 & 0.40 & 0.40 & 1.4 \\
\hline Area II $(0-20 \mathrm{~cm})$ & 4.2 & 0.27 & 0.12 & 1.1 & 0.60 & 1.00 & 7.4 \\
\hline Area II $(20-40 \mathrm{~cm})$ & 4.1 & 0.22 & 0.11 & 0.5 & 0.25 & 1.15 & 7.9 \\
\hline
\end{tabular}

\section{Discussion}

Until then, a reduction both in diversity and volume of woody vegetation can be observed, at environments where there are rocky outcrops, in comparison with environments without them. Studies conducted by Mota et al. (2014) at Parque Estadual do Biribiri (PEB), Diamantina, Minas Gerais State (Southeastern Brazil), reinforce that the presence of rocky outcrops inside some parcels influence the differerentiation of floristic composition. Moura et al. (2010) evidence the good species richness for a rocky Cerrado sensu stricto area at Parque Estadual dos Pireneus, Goiás State (Mid-west Brazil), in deep and well-drained latosoils. Similar studies conducted by Amaral et al. (2006), Felfili and Fagg (2007), Felfili et al. (2007), Miranda et al. (2007), Moura et al. (2007) and Pinto et al. (2009) corroborate this tendency, suggesting that other factors, besides the presence of rock, may also influence the floristic composition of the studied environments.

The PCA analysis also pointed to a strong dependence for H. stignocarpa and Q. parviflora, while evidenced a notorious dominance of both species in their respective substrates, what is confirmed by the numeric factor, all the 85 individuals of $H$. stignocarpa were registered only at environment I and Q. parviflora demonstrated the same numerical tendency, for of the 101 individuals registered, $94(93 \%)$ are at environment II. A. occidentale seems to vie the dominance with $Q$. parviflora in the rocky substrate, whilst $C$. fasciculata demonstrates good competitiveness in environment I. The presence of $A$. leptopetala in the vie for dominance in environment I suggests that the Caatinga vegetation may be invading the Cerrado fragment.

The evidence for these hierarchical variations between woody species populations in different kinds of substrates demonstrated in this study can be explained by Ricklefs (2010), who states that plants, by exploiting resources punctually and having a sessile life habit, have the abiotic factors as the main selective pressures to evolution, thus limiting species distribution.

Gomes et al. (2011) point that $A$. occidentale and $Q$. parviflora were important for the vegetation structure in deep soils of typical Cerrado and shallow soils with rocky outcrops at Parque Municipal do Bacaba, Nova 
Xavantina, Mato Grosso state (Mid-west Brazil). Lemos et al. (2013), in similar studies in a Cerrado sensu stricto area in Tocantins state (Mid-west Brazil) suggest that $A$. occidentale and $Q$. parviflora seem not to be influenced by different kinds of substrates. Ratter et al. (2003) point that taxa of the genus Qualea are well-adapted to different substrates, and thus are widely distributed by the Cerrado biome.

Those facts do not corroborate this study, for as demonstrated, A. occidentale and $Q$. parviflora significantly lose their representativeness in number of individuals in environments where rocky outcrops are absent, reinforcing the hypothesis that the presence of rocky outcrops is not the only determinant factor that may be influencing the distribution and competitiveness dynamics of the studied plant communities.

There were little variations in soil density between the two environments. Environment I demonstrated a slightly higher density in comparison to environment II, but the density value did not surpass $1.39 \mathrm{Kg} / \mathrm{dm}^{3}$. Skopp (2002) and Donagemma et al. (2016) understand that sandy soil density varies from 1.4 to $1.9 \mathrm{~g} \mathrm{~cm}^{-3}$, what reflects the occurrence of a greater clustering in sandy materials; in this case, the value of $1.85 \mathrm{~g} \mathrm{~cm}^{-3}$ is critical for root development.

Converting the maximum value in this study to the values evaluated by Skopp (2002) and Donagemma et al. (2016), the maximum of $1.3 \mathrm{~g} \mathrm{~cm}^{-3}$ was obtained, whic suggests that soil density is not a limitant factor to the development of the woody species of Serra do Boqueirão.

Donagemma et al. (2016) confirm that Quartzarenics Neossolos stand out in the Brazilian System of Soil Classification (SiBCS), having sandy texture in all horizons, reaching $1.50 \mathrm{~m}$ from the surface or reaching the lithic bed, covering ca. $15 \%$ of the Cerrado area in Brazil.

Tognon (1991) defends that soil porosity interferes in aeration, water conduction and retention, resistance to penetration and ramification of roots, and consequently in the utilization of available water and nutrients. Pessoa-de-Souza et al. (2015), in studies conducted with Quartzarenics Neossolos corroborate the obtained results, where the total porosity volume did not reach $50 \%$, and by the way evidenced a kind of orthic Neossolo Quartzarênico, for not offering resistance to water percolation, thus allowing a higher physical-hydric dynamics of the terrain, which also contributes to a susceptibility to water erosion due to the high level of porosity.

Balbino-Miguel et al. (2010) declared that in soils with $\mathrm{pH}$ below 5.0, the high concentration of available aluminum $(\mathrm{Al})$ is one of the factors that cause major toxicity problems, which is a limiting factor to plant growth, since the presence of $\mathrm{Al}$ reduces root growth and development, as well as decreases nutrient absorption. Haridasan (2000), Salvador et al. (2000), Echart and CavallI-Molina (2001), and Gomes et al. (2011) corroborated these same trends and help us explain the loss of richness and dominance volume in the environment II.

Abreu et al. (2012) confirm a high aluminum saturation associated with environment with characteristics of sandy soils and observe that the physico-chemical analyses of the soil better explain the structural and floristic differences of the vegetation.

However, $Q$. parviflora and A. occidentale do not seem to be limited in relation to the aluminum concentration in the mentioned environment, indicating a type of tolerance to this element, judging by the fact that the PCA in consonance with the absolute dominance values, demonstrated that these species have a larger domain established in substrates with high aluminum saturation and acid $\mathrm{pH}$.

Haridasan (2000) points out that several species of family Vochysiaceae are aluminum accumulators a trait which, therefore, gives them an adaptive advantage in environments with the presence of exchangeable aluminum.

Mota et al. (2014), following the same trend of the results obtained in this study, confirmed this hypothesis and indicated that Vochysiaceae and Fabaceae are the most representative families of the Brazilian Cerrado and that, nevertheless Fabaceae, despite having the nitrogen fixation capacity as one of its adaptive advantages for this domain, seems to be more influenced by rocky outcrops than Vochysiaceae.

The resistance of $A$. occidentale found in the present study may be a reflection of gene mutations, which conferred adaptive success through the limiting factors of the environment. Echart and Cavalli-Molina (2001) explain that Al tolerance can be controlled in different ways, from a single dominant gene to a complex one with additive effect genes acting on different biochemical pathways. In genetic studies conducted by EMBRAPA (2018) in A. occidentale seedlings, aluminum tolerance was pointed out in two distinct genotypes (CCP 06 and BRS 275), in which no symptoms of toxicity were present in presence of this element within 60 days of application. 
Neri et al. (2007) confirm that most of Cerrado soil has acid pH and low concentration of available calcium and magnesium, with high concentration of exchangeable aluminum, which corroborates the characteristics of most of the soil of the studied area. It suggests that the chemical attributes of the soil associated with high all concentration may be the decisive factors for the establishment of common Cerrado species in the middle of Caatinga of Serra do Boqueirão, since Cerrado species are more adapted to inhabit substrates under these conditions.

\section{Conclusions}

The species Anacardium occidentale, Hymenaea stigonocarpa and Qualea parviflora were dominant in the Cerrado environment under study.

There were differences in diversity, hierarchy and dominance of arboreous plant populations between environments with and without the presence of rocky outcrops.

The physical characteristics of the soil suggest that the Cerrado fragment is susceptible to water erosion due to the high level of porosity.

Aluminum in consonance with the rocky outcrops, act as limiting abiotic factor for the establishment and development of woody species in the Cerrado fragment. Q. parviflora and A. occidentale have some kind of tolerance to aluminum toxicity in environments with $\mathrm{pH}$ below 5.0.

\section{Acknowledgements}

The authors thank Coordenação de Aperfeiçoamento de Pessoal de Nível Superior (CAPES); Fundação Cearense de Apoio ao Desenvolvimento Científico e Tecnológico (FUNCAP); Conselho Nacional de Desenvolvimento Científico e Tecnológico (CNPq), Embrapa Semiárido and Universidade Regional do Cariri (URCA).

\section{References}

Abreu, M. F., Pinto, L. M., Gomes, L., Oliveira, E. A., Marimon, B. S., Marimon-Junior, B. H., ... Lenza, E. (2012). Influence of edaphic variables on the floristic composition and structure of the tree-shrub vegetation in typical and rocky outcrop cerrado areas in Serra Negra, Goiás State, Brazil. Brazilian Journal of Botany, 35(3), 259-272. https://doi.org/10.1590/S1806-99592012000300005

Amaral, A. G., Pereira, F. F. O., \& Munhoz, B. R. (2006). Fitossociologia de uma área de cerrado rupestre na fazenda Sucupiara, Brasília-DF. Revista Cerne, 12(4), 350-359.

Balbino-Miguel, P. S., Gomes, F. T., Rocha, W. S. D., Martins, C. E., Carvalho, C. A., \& Oliveira, A. V. (2010). Efeitos tóxicos do alumínio no crescimento das plantas: Mecanismos de tolerância, sintomas, efeitos fisiológicos, bioquímicos e controles genéticos. CES Revista, 24(1).

Bortolon, E., \& Bortolon, L. (2016). Caracterização, potencial agrícola e perspectivas de manejo de solos leves no Brasil. Pesq. Agropec. Bras., 51(9), 1003-1020. https://doi.org/10.1590/s0100-204x2016000900001

Brasil. (2019). Projeto Flora do Brasil 2020. Retrieved from http://floradobrasil.jbrj.gov.br

Calixto Júnior, J. T., \& Drumond, M. A. (2014). Estudo comparativo da estrutura fitossociológica de dois fragmentos de Caatinga em níveis diferentes de conservação. Pesquisa Florestal Brasileira Colombo, 34(80), 1-11. https://doi.org/10.4336/2014.pfb.34.80.670

Castro, A. A. J. F., \& Martins, F. R. (1994). Comparação Florístico-geográfica (Brasil) e Fitossociológica (Piaui, São Paulo) de amostras de Cerrado (Tese (doutorado) em Botância, Universidade Federal do Piauí, Brazil).

Donagemma, G. K., Freitas, P. L., Balieiro, F. C., Fontana, A., Spera, S. T., Lumbreras, J. F., .. Cavalli-Molina, S. (2001). Fitotoxicidade do alumínio: Efeitos, mecanismo de tolerância e seu controle genético. Revista Ciência Rural, 31(3), 531-541, https://doi.org/10.1590/S0103-84782001000300030

Felfili, J. M., \& Fagg, C. W. (2007). Floristic composition, diversity and structure of the "cerrado" sensu stricto on rocky soils in northern Goiás and southern Tocantins, Brazil. Revista Brasil Bot., 30(3), 375-385. https://doi.org/10.1590/S0100-84042007000300004

Felfili, J. M., Eisenlohr, P. V., Melo, M. M. R. F., Andrade, L. A., \& Meira-Neto, J. A. A. (2013). Fitossociologia no Brasil: Métodos e Estudos de caso. Universidade Federal de Viçosa, Brazil.

Felfili, J. M., Rezende, A. V., \& Silva Júnior, M. C. (2007). Biogeografia do Bioma Cerrado: Vegetação e Solos da Chapada dos Veadeiros. Editora da Universidade de Brasília, Brasília.

Ferraz, R. C., Mello, A. A., Ferreira, R. A., \& Nacimento-Prada, A. P. (2013). Levantamento Fitossociológico em área de caatinga no monumento natural Grota do Angico, Sergipe, Brasil. Revista Caatinga, 26(3), 89-98. 
Figueiredo, M. A., \& Fernandes, A. (1987). Encraves de Cerrado no interior do Ceará. Revista Cien. Agron., $18(2), 103-106$.

FUNCEME (Fundação Cearense de Meteorologia e Recursos Hídricos). (2019). Calendário chuvoso. Ceará, Brazil. Retrieved from http://www.funceme.br

Gomes, L., Lenza, E., Maracahipes, L., Marimon, B. S., \& Oliveira, E. A. (2011). Comparações florísticas e estruturais entre duas comunidades lenhosas de cerrado típico e cerrado rupestre, Mato Grosso, Brasil. Revista Acta Botânica Brasílica, 25(4), 865-875. https://doi.org/10.1590/S0102-33062011000400013

Hammer, O., Harper, D. A. T., \& Ryan, P. D. (2011). PAST: Paleontological Statistic software package for education and data analysis. Paleontologia Eletronica, 4(1), 1-9.

Haridasan, M. (2000). Nutrição mineral de plantas nativas do cerrado. Revista Brasileira de Fisiologia Vegetal, $12(1), 54-64$.

IGBE (Instituto Brasileiro de Geografia e Estatística). (2018). Biomas. Instituto Brasileiro de Geografia e Estatística, Brazil. Retrieved August 18, 2018, from ftp://ftp.ibge.gov.br/Cartas_e_Mapas/Mapas_Murais

INPE (Instituto Nacional de Pesquisas Espaciais). (2019). Estado Ceará-Lavras da Mangabeira (Nosa-12/AV/HRR). Centro de Previsão do Tempo e Estudos Climáticos (CPTEC).

IPECE (Instituto de Pesquisa Econômica do Ceará). (2019). Mapas Classes de Solos. Secretaria do Planejamento e Gestão, IPECE, Ceará, Brazil. Retrieved from http://www2.ipece.ce.gov.br/atlas/capitulo1/12/pdf/1.2.4 classes_de_solos.pdf

IPECE (Instituto de Pesquisa Econômica do Ceará). (2019). Perfil Municipal de Lavras da Mangabeira. Secretaria do Planejamento e Gestão, IPECE, Ceará, Brazil. Retrieved from http://ipecedata.ipece.ce.gov.br/ ipece-data-web/module/perfil-municipal.xhtml

Klink, C. A., \& Machado, R. B. (2005). A conservação do cerrado brasileiro. Megadiversidade, 1(1), $147-155$.

Koppen, W., \& Geiger, R. (1928). Klimate der Erde. Gotha: Verlag Justus Perthes.

Lemos, H. L., Pinto, J. R. R., Mews, H. A., \& Lenza, E. (2013). Structure and floristic relationships between Cerrado sensu stricto sites on two types of substrate in northern Cerrado, Brazil. Biota Neotrop, 13(4), 121-132. https://doi.org/10.1590/S1676-06032013000400013

Lemos, R. C., \& Santos, R. D. dos. (1984). Manual de descrição e coleta de solo no campo (2nd ed.). Campinas: SBCS/SNLCS.

Lima, T. A., Pinto, J. R. R., Lenza, E., \& Pinto, A. S. (2010). Florística e estrutura da vegetação arbustivo-arbórea em uma área de cerrado rupestre no Parque Estadual da Serra de Caldas Novas, Goiás. Revista Biota Neotrop, 10(2). https:/doi.org/10.1590/S1676-06032010000200020

Lopes, A. S., \& Cox, F. R. (1977). A survey of the fertility status of surface soils under 'cerrado' vegetation in Brazil. Soil Science Society of America Journal, 41, 741-747. https://doi.org/10.2136/sssaj1977.036159 95004100040026x

Miranda, S. C., Silva Júnior, M. C., \& Salles, L. A. (2007). A comunidade lenhosa de cerrado rupestre na Serra Dourada, Goiás. Heringeriana, 1, 43-53.

Missouri Botanical Garden. (2008). National Historic Landmark summary listing. National Park Service.

Moro, M. F., Castro, A. S. F., \& Araujo, F. S. (2011). Composição florística e estrutura de um fragmento de vegetação savânica sobre os tabuleiros pré-litorâneos na zona urbana de Fortaleza, Ceará. Rodriguésia, 62, 407-423. https://doi.org/10.1590/2175-7860201162214

Mota, S. L. L., Pereira, I. M., Machado, E. L. M., Oliveira, M. L. R., Bruzinga, J. S., Farnezi, M. M. M., \& Meira-Junior, M. S. (2014). Influência dos Afloramentos Rochosos sobre a Comunidade Lenhosa no Cerrado stricto sensu. Floresta e Ambiente, 21(1), 8-18. https://doi.org/10.4322/floram.2014.009

Moura, I. O., Gomes-Klein, V. L., Felfili, J. M., \& Ferreira, H. D. (2010). Diversidade e estrutura comunitária de cerrado sensu stricto em afloramentos rochosos no Parque Estadual dos Pireneus, Goiás. Revista Brasil. Bot., 33(3), 455-467. https://doi.org/10.1590/S0100-84042010000300008

Moura, I. O., Gomes-Klein, V. L., Felfili, J. M., \& Ferreira, H. D. (2007). Fitossociologia da comunidade lenhosa de uma área de cerrado rupestre no Parque Estadual dos Pireneus, Pirenópolis, Goiás. Revista de Biologia Neotropical, 4(2), https://doi.org/1010.5216/rbn.v4i2.5208 
Mueller-Dumbois, D., \& Ellenberg, H. (1974). Aims and methods of Vegetation Ecology. J. Wiley \& Sons, New York.

Nepomuceno, I. V., et al. (2016). Flora de um enclave de cerrado no município de granja, ce-dados preliminaries. Congresso Internacional da Diversidade do Semiarido, I., Campina Grande, PB.

Neri, A. V., Meira-Neto, J. A. A., Silva A. F. da., Martins, S. V., \& Batista, M. L. (2007). Análise da estrutura de uma comunidade lenhosa em área de cerrado sensu stricto no município de Senador Modestino Gonçalves, Norte de Minas Gerais, Brasil. Revista Árvore, 31(1), 123-134. https://doi.org/10.1590/S0100-67622007 000100014

Orloci, L. (1966). Genometric models in ecology. I. The theory and application of some ordination methods. $J$. Ecol., 54, 193-215. https://doi.org/10.2307/2257667

Pearson, K. (1901). On lines and planes of closest fit to systems of points in space. Philosophical Magazine, 2(11), 559-572. https://doi.org/10.1080/14786440109462720

Pessoa-Desouza, M. A., Almeida, R. T. S., Neves, M. N., Castro, J. P. V., \& Castro, S. S. (2015). Comportamento químico de Neossolos Quartzarênicos em mineiros, Sudoeste Goiano. Geociências, 34(3), 335-347.

Pinto, J. R. R., Lenza, E., \& Pinto, A. S. (2009). Composição florística e estrutura da vegetação arbustivo-arbórea em um cerrado rupestre, Cocalzinho de Goiás, Goiás. Revista Brasileira de Botânica, 32(1), 1-10. https://doi.org/10.1590/S0100-84042009000100002

Pivello, V. R., \& Coutinho, L. M. (1996). A qualitative successional model to asssist in the management of Brazilian cerrados. Forest Ecology and Management, 87, 127-138. https://oi.org/10.1016/S0378-1127 (96)03829-7

Ratter, J. A., Bridgewater, S., \& Ribeiro, J. F. (2003). Analysis of the floristic composition of the Brazilian cerrado vegetation III: Comparison of the woody vegetation of 376 areas. Revista Edinburgh Journal of Botany, 60, 57-109. https://doi.org/10.1017/S0960428603000064

Ribeiro, J. F., \& Walter, B. M. T. (2008). As principais fitofisionomias do Bioma Cerrado. In S. M. Sano, S. P. Almeida \& J. F. Ribeiro (Eds.), Cerrado: Ecologia e flora (pp. 151-212). Embrapa Cerrados, Planaltina.

Ricklefs, R. E. (2010). Economia da Natureza (6th ed., p. 503). Guanabara Koogan, Brazil.

Salvador, J. O., Moreira, A., Malavolta, E., \& Cabral, C. P. (2000). Influência do alumínio no crescimento e na acumulação de nutrientes em mudas de goiabeira. Revista Bras. Ci. Solo, 24, 787-796. https://doi.org/ 10.1590/S0100-06832000000400011

Sheperd, G. J. (2010). FITOPAC 2: Manual do usuário (p. 91). Campinas: Unicamp.

Silva, E. M., Lima, J. E. F. W., Azevedo, J. A., \& Rodrigues, L. N. (2006). Valores de tensão na determinação da curva de retenção de água de solos do Cerrado. Pesquisa Agropecuária Brasileira, 41, 323-330. https://doi.org/10.1590/S0100-204X2006000200018

Silveira, E. P. (2010). Florística e estrutura da vegetação de Cerrado sensu stricto em Terra Indígena no noroeste do estado de Mato Grosso (Dissertação (Mestrado em Ciências Florestais e Ambientais), Universidade Federal de Mato Grosso, Cuiabá, Mato Grosso, Brasil). https://oi.org/10.5216/ rbn.v6i2.12849

Skopp, J. M. (2002). Physical properties of primary particles. In A. W. Warrick (Ed.), Soil physics companion (pp. 1-16). Boca Raton: CRC Press. https://doi.org/10.1201/9781420041651.ch1

Taniguchi, C. A. K. (2018). Efeitos do alumínio no desenvolvimento de mudas de cajueiro. Boletim de pesquisa e desenvolvimento 178. Embrapa Agroindústria Tropical.

Tognon, A. A. (1991). Propriedades físico-hídricas do Latossolo Roxo da região de Guairá-SP sob diferentes sistemas de cultivo (Dissertação (Mestrado) Escola Superior de Agricultura de Luiz de Queiroz, Piracicaba, São Paulo, Brasil).

Tropicos. (2019). Missouri Botanical Garden-Banco de dados online com mais de 3.766.657 espécies. Retrieved from https://www.tropicos.org 


\section{Copyrights}

Copyright for this article is retained by the author(s), with first publication rights granted to the journal.

This is an open-access article distributed under the terms and conditions of the Creative Commons Attribution license (http://creativecommons.org/licenses/by/4.0/). 